\title{
Platelet-rich plasma injection in a patient with adhesive capsulitis due to chronic kidney disease
}

\author{
Kronik böbrek hastalığına bağıı adhezif kapsülitli hastada trombosit zengin plazma \\ enjeksiyonu
}

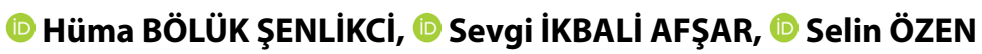

To the Editor,

$\% 75$ of hemodialysis patients suffer from pain whether causes from musculuskeletal system or not. ${ }^{[1]}$ Adhesive capsulitis is a common problem in patients with chronic kidney disease. Patients suffer from joint stiffness and painful joint movement. However, symptoms can relieve after 3 years from beginning, some may be permanent. Conservative treatments consist non-steroid antiinflamatory drugs, intraarticular injections and physical therapy. [2, 3] Newer approches such as platelet-rich plasma injections (PRP) also can be applied but there is little evidence for the effectiveness of PRP in patients with adhesive capsulitis. PRP consists higher level of growth factors and thrombocytes that have regenerative potentials. ${ }^{[4]}$

A 70 year-old woman, receives dialysis treatment admitted to our out-patient clinic with stiffness and pain in her right shoulder. Symptoms lasted for 5 years. Her diagnosis was confirmed with MRI as adhesive capsulitis. Shoulder movements were limited. Affected side was right and arteriovenous fistulas were on the left side. Patient had received different conservative treatments many times such as anti inflammatory drugs, corticosteroid injections and physical therapy. After the signed informed consent, the procedure began to be applied as planned; 3 times, 15 days between each PRP injection. Visual analog scale (VAS), disabilities of the arm, shoulder and hand questionnare (DASH) and range of motion (ROM) of her right shoulder were evaluated before the procedure process. ROM, DASH and VAS were assessed every 2 weeks after each injection. ROM evaluation was done with goniometer. Pre-treatment ROM was $75^{\circ}$ for flexion, $30^{\circ}$ for extension, $45^{\circ}$ for abduction, $0^{\circ}$ for internal rotation and $30^{\circ}$ for external rotation. At the last assesment average ROM increased on flexor, abductor and internal rotator sides. It was evaluated $90^{\circ}$ for flexion, $90^{\circ}$ for abduction and $30^{\circ}$ for internal rotation. However, she didn't report any improvement for function and pain based on DASH and VAS.

PRP is used in the treatment of shoulder pathologies. Previously, it was revealed that they lead to decrease pain and improve functions in patients with rotator cuff partial-thickness tears, ${ }^{[5]}$ but there is limited evidence for patients who have adhesive capsulitis due to chronic kidney disease or other co-morbid factors. Only a case report mentioned recovery after PRP in a patient with adhesive capsulitis without any leading co-morbid factors. ${ }^{[6]}$ Our patient reported little improvement in ROM but didn't report any recovery for pain and functional outcome. PRP should be kept in mind in patients with adhesive capsulitis to improve ROM but there is need for further studies additionally consisting subjects that have co-morbid diseases. 


\section{References}

1. Yeşil S, Karslı B, Kayacan N, Süleymanlar G, Ersoy F. Pain evaluation in patients with chronical renal failure undergoing hemodialysis. Agri 2015;27:197-204. [CrossRef]

2. Robinson $C M$, Seah KT, Chee YH, Hindle P, Murray IR. Frozen shoulder. J Bone Joint Surg Br 2012;94(1):1-9. [CrossRef]

3. Sucuoğlu $H$, Süzen Özbayrak $S$, Uludağ $M$, Tüzün Ş. Shortterm efficacy of joint and soft tissue injections for musculoskeletal pain: An interventional cohort study. Agri
2016;28(2):79-88. [CrossRef]

4. Marx RE. Platelet-rich plasma: evidence to support its use. J Oral Maxillofac Surg 2004;62(4):489-96. [CrossRef]

5. Mei-Dan O, Carmont MR. The role of platelet-rich plasma in rotator cuff repair. Sports Med Arthrosc Rev 2011;19(3):244-50. [CrossRef]

6. Aslani H, Nourbakhsh ST, Zafarani Z, Ahmadi-Bani M, Ananloo ME, Beigy M, et al. Platelet-Rich Plasma for Frozen Shoulder: A Case Report. Arch Bone Jt Surg 2016;4(1):90-3. 